\title{
Accumulation of mercury in the tissues of the common octopus Octopus vulgaris (L.) in two localities on the Portuguese coast
}

\author{
Sónia Seixas ${ }^{\mathrm{a}, *}$, Paco Bustamante ${ }^{\mathrm{b}, 1}$, Graham Pierce ${ }^{\mathrm{c}, 2}$ \\ ${ }^{a}$ Rua Escola Politécnica, Universidade Aberta, 147, Lisboa, Portugal \\ ${ }^{\mathrm{b}}$ Laboratoire de Biologie et Environnement Marins, FRE 2727, Université de La Rochelle, 22, Avenue Michel Crépeau, \\ F-17042 La Rochelle, France \\ ${ }^{\mathrm{c}}$ Department of Zoology, School of Biological Sciences, University of Aberdeen, Tillydrone Avenue, Aberdeen AB24 2TZ, United Kingdom
}

Received 11 March 2004; received in revised form 30 August 2004; accepted 31 August 2004

\begin{abstract}
Mercury concentrations were measured in tissues of 12 individuals of Octopus vulgaris, captured by the commercial fishery at two points along the Portuguese coast, Viana do Castelo and Cascais, in spring 2002. Concentrations were determined in six tissues (digestive gland, branchial hearts, gills, mantle, arms, and gonads). Correlations between mercury concentrations in different tissues were examined as were correlations between mercury levels and total length, mantle length, weight, gonadosomatic index, digestive gland index, and state of maturation. Differences between sexes and localities were analysed.

The concentration of mercury in the digestive gland (Viana, $0.58 \pm 0.08$, and Cascais, $3.43 \pm 2.57 \mathrm{mg} / \mathrm{kg}$ dry weight) was higher than in the other tissues, and values were generally similar to those recorded in previous studies on octopods. Arm muscle contained most of the mercury with $56 \%$ of the total body burden followed by the digestive gland with $31 \%$, mantle with $11 \%$, gills with $0.8 \%$, gonad with $0.5 \%$, and branchial heart with $0.2 \%$. In all tissues, mercury concentrations were slightly higher in samples from Cascais than in Viana do Castelo, which is consistent with higher concentrations recorded in seawater at Cascais. Levels of mercury determined in octopus were within the range of values legally defined as safe for human consumption.
\end{abstract}

(C) 2004 Elsevier B.V. All rights reserved.

Keywords: Toxic element; Marine pollution; Cephalopods; Mercury, Octopus

* Corresponding author. Tel.: +351 213916300; fax: +351 213969293.

E-mail addresses: sonia@univ-ab.pt (S. Seixas), pbustama@univ-lr.fr (P. Bustamante), g.j.pierce@abdn.ac.uk (G. Pierce).

1 Tel./fax: +33 546500294 .

2 Tel.: +44 1224 272459; fax: +44 1224272396.

\section{Introduction}

Mercury $(\mathrm{Hg})$ is a toxic heavy metal of particular concern as an environmental pollutant in marine food webs. It has no known biological role and is toxic to all living organisms. In human beings, mercury poisoning is known as the Minamata disease, after 
the consequences of the discharge of 200-600 tonnes of mercury into Minamata Bay (Japan) between 1932 and 1968 (Smith and Smith, 1975).

Mercury is rare in the earth's crust, being present at concentrations between 0.1 and $1 \mathrm{mg} / \mathrm{kg}$ (Landis and $\mathrm{Yu}, 1999)$. It is used in various industrial processes, including the production of chlorine, caustic soda, barometers, batteries, UV spectrophotometers, lighting, paints, pesticides, pharmaceuticals, cosmetics, toiletries, and military hardware (WHO, 1972; Law, 1993; Landis and Yu, 1999). The principal forms of mercury discharged into the environment by industry are metallic mercury, inorganic mercury, aryl-, alkyl-, and alkoxyalkylmercury compounds (WHO, 1972).

Mercury is transported in the environment by air and water, as well as by biological organisms through the food chain (IPCS, 2003). Mercury in the sea can arise from runoff water-contaminated by either natural and/or anthropogenic sources-or from air deposition (NAS, 2000). Although most indications are that atmospheric pollution from industrial production has decreased in recent years, reflecting in part the introduction of restrictive regulations (Boening, 2000), contamination of mercury in the aquatic environment remains significant.

In aqueous environments, inorganic mercury is transformed into organic mercury compounds by a variety of microorganisms, mainly sulphur-reducing forms of anaerobic bacteria (WHO, 1972; Gilmour and Henry, 1991; Regnell and Tunlid, 1991; IPCS, 2003). These processes of biotransformation can occur in the sediment or the water column (EPA, 2001).

Methyl mercury is the most stable organic mercury compound (WHO, 2003) and is the predominant form of mercury in seafood (NAS, 1991). This form is the most toxic to organisms. The nervous system is the critical organ for chronic mercury exposure, and methyl mercury can react directly with important receptors in the nervous system (WHO, 1990; Horvat, 2001).

Mercury inhibits enzyme activity and provokes cell damage. Organic mercury has a high affinity to lipids, allowing movement across cell membranes, and can interfere with cell metabolism (Pinho et al., 2002). Methyl mercury interferes with the process of cell division, causing daughter cells to receive an unequal number of chromosomes (nondisjunction; Law, 1993).
In cetaceans, mercury is believed to be an immunosuppressant (Bennett et al., 2001).

As mercury elimination rates by organisms are very low, its concentration through food chains tends to increase (Pinho et al., 2002). Bioaccumulation in food webs of mercury is thus a concern. Predatory organisms at the top of aquatic food webs generally have higher methyl mercury concentrations. Nearly all of the mercury that bioaccumulates in upper trophic level tissue is methyl mercury (Bloom, 1992; EPA, 2001).

Fish and shellfish tend to contain high concentrations of mercury in relation to other animals, and over $90 \%$ is in the form of methyl mercury, principally because fish feed on aquatic organisms that contains this compound (WHO, 2003). The amount of mercury in fish is normally correlated with a number of factors including the size and age of the fish, its trophic position, as well as the mercury content in water and sediment and the $\mathrm{pH}$ of the water (WHO, 2003).

Biochemical and physiological mechanisms allowing mollusc species to accumulate and tolerate high amounts of heavy metals are based on their metal handling by metallothioneins. These are proteins that inactivate toxic metal ions by binding them to sulphur atoms of the peptide cysteine residues, and they may represent a useful biomarker for heavy metal contamination (see, e.g., Isani et al., 2000).

However, mercuric (inorganic) mercury, but not methyl mercury, induces synthesis of metallothionein (Goyer, 1995). In marine mammals, methyl mercury is detoxified by a chemical mechanism involving selenium (Dietz et al., 2000). In general, the presence of selenium in similar concentrations as mercury in tissues of marine animals is taken to be indicative of successful detoxification. However, the mechanisms of interaction between mercury and selenium are not well understood (Frisk, 2001; Peterson et al., 2003).

Levels of mercury in the octopus Eledone cirrhosa have been documented for the Tyrrhenian Sea (Barghigiani et al., 1991; Rossi et al., 1993). The latter authors noted that E. cirrhosa was a "strong accumulator" of mercury and raised the question of whether frequent consumption of this cephalopod was harmful to humans.

The aim of this study was to determine the influence of biological and ecological factors (sex, 
size/weight, and location) on the bioaccumulation of mercury in the tissues of the common octopus Octopus vulgaris. Therefore, mercury concentrations have been determined in the digestive gland, branchial hearts, arms, mantle, gills, and gonads of male and female octopus from two sites on the

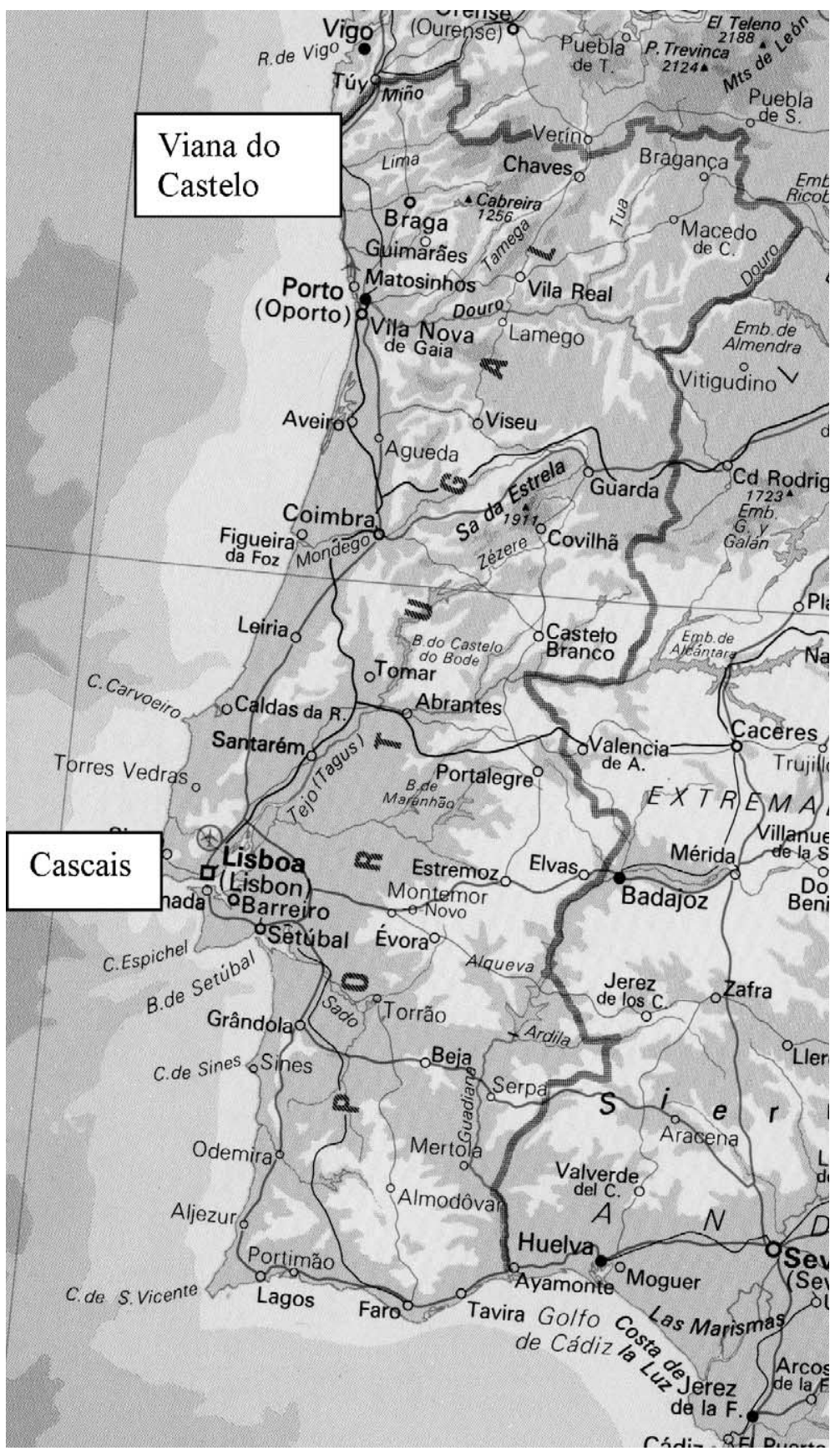

Fig. 1. Map showing location of the sampling ports. 
Portuguese coast. Finally, mercury concentrations in the edible tissues of the octopus, i.e., arms and mantle, are discussed in relation to possible adverse effects on human health.

\section{Materials and methods}

\subsection{Sampling and sample preparation}

Octopus were sampled from commercial fishery landings in Cascais, which is situated in the centre of Portugal, with a strong influence of the Tagus River (the largest river in Portugal), and in Viana do Castelo, situated in the north of Portugal and influenced by the Rias Galegas and the rivers closer to the area (Lima river and Minho river; Fig. 1).

Octopus were sampled in the spring of 2002, three females and three males from each area. This season was chosen because it is that in which mercury levels in the Tagus estuary are highest (Simas, 1998).

Total length, mantle length, total weight, sex, and maturation state were determined in each animal. The maturation state was evaluated by direct observation of colours of reproductive structures (Gonçalves, 1993). The maturity index used was from Guerra (1975) and is based on microscopic analyses and measurements of ovules and spermatophores.

Fresh animals were taken back to the laboratory and dissected. The tissues sampled were arm, mantle, digestive gland, branchial hearts, gills, and gonads (ovary or testis). Gonad weights and digestive gland weights were expressed as percentages of total body weight, i.e., gonadsomatic index (GSI) and digestive gland index (DGI; see Silva et al., 2002).

Prior to the determination of the concentrations of mercury, all these samples were stored frozen between -20 and $-40{ }^{\circ} \mathrm{C}$ in individual plastic bags.

\subsection{Analytical procedure}

Samples were freeze-dried. The dry/wet weight was calculated for tissues analysed. After powdering in a porcelain mortar and pestle, aliquots ranging from 10 to $20 \mathrm{mg}$ of dried material were analysed directly using an Advanced Mercury Analyser spectrophotometer (Altec AMA 254). Mercury determination involved evaporation of mercury by heating to $800{ }^{\circ} \mathrm{C}$ under oxygen for $3 \mathrm{~min}$ and subsequent amalgamation on a gold net. Afterwards, the net was heated to liberate the collected mercury, which was subsequently measured by UV atomic absorption spectrophotometry. At least two analyses of each sample were carried out to ensure consistent results. Quality assurance was assessed using lobster hepatopancreas TORT-2 (NRCC) and dogfish liver DOLT-2 (NRCC) as reference materials. These standards were treated and analysed under the same conditions as the octopus samples, and recoveries of $\mathrm{Hg}$ ranged from $99 \%$ to $101 \%$. Detection limit, calculated as three standard deviations of the mean of eight blanks was $0.005 \mathrm{mg} \mathrm{kg}^{-1}$ dry weight. The

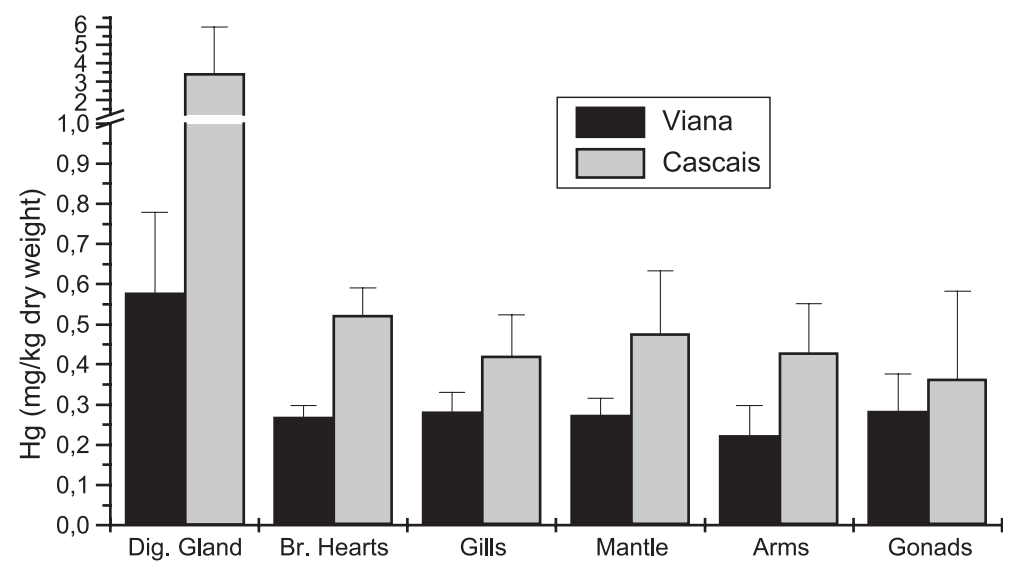

Fig. 2. Concentrations of mercury in octopus from Viana do Castelo and Cascais in digestive gland, branchial hearts, gills, mantle, arms and gonads. 


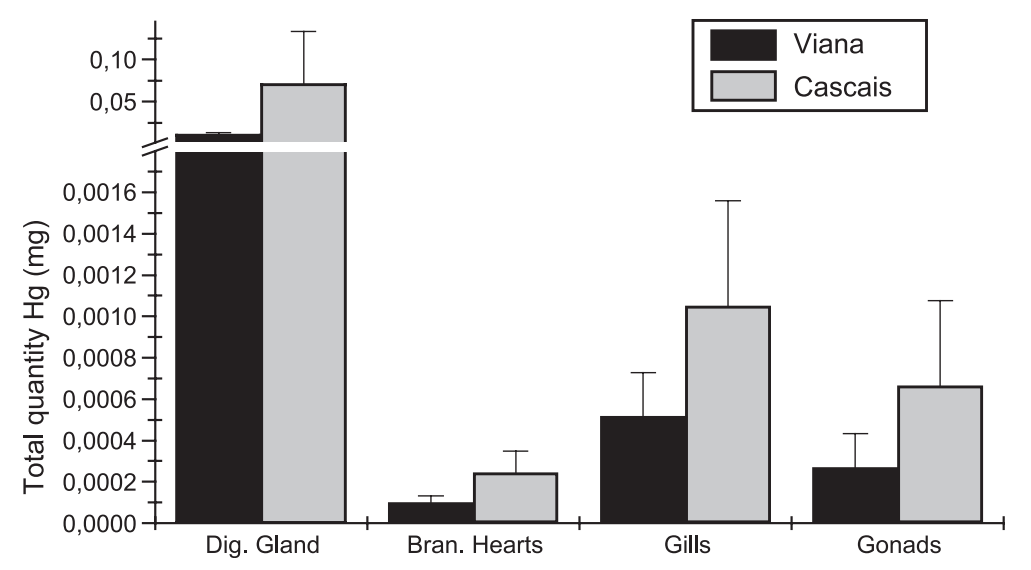

Fig. 3. Total quantity of mercury in the digestive gland, branchial hearts, gills, and gonads from Viana and Cascais.

results for each tissue are given relative to the dry weight ( $\mathrm{mg} \mathrm{kg}^{-1}$ dry weight).

The multiplication factors to convert wet weight to dry weight concentrations were digestive gland-2.3, branchial hearts -4.4 , gills -5 , mantle -5 , arms -5 , and gonads -5.5 .

\subsection{Statistical procedures}

Statistical analysis was carried out using STATISTICA (StatSoft, 1995). Two-way ANOVA was used to test the influence of sex and location on mercury concentrations in all tissues. To analyse the correlations between state of maturation and concentration in tissues, we used Spearman rank order correlations. For relations between other parameters such as total length and total weight and concentrations of elements, we used the Pearson coefficient of correlation. To determine the similarity of different samples, we used Ward's Method of tree clustering, which is based on an analysis of variance approach to evaluate the distance between clusters.

\section{Results}

The mean and standard deviation of the weight and length of octopus captured in Viana do Castelo were $1083 \pm 224.9 \mathrm{~g}$ and $77 \pm 4.8 \mathrm{~cm}$. In Cascais, the values were $1059 \pm 439 \mathrm{~g}$ and $76 \pm 9 \mathrm{~cm}$.

The concentrations and estimated total amounts of mercury in tissues analysed are shown in Figs. 2 and
3. We did not separate the females and males because there were no significant differences between them (ANOVA; Table 1). It is apparent that the concentrations of mercury were highest in digestive gland samples, and higher in samples from Cascais than in those from Viana do Castelo. The between-area difference in concentration was significant for all organs except gonads (ANOVA; Table 1).

There were no significant correlations between the concentration of mercury in tissues and any of the measures of size, condition, and reproductive status (body weight, total length, maturation state, GSI, DGI; see Table 2).

Mercury concentrations in arms, mantle, gills, and branchial hearts were strongly positively correlated (Table 3). Concentrations in the digestive gland were correlated only with those in the branchial heart. Concentrations in gonads were correlated with those in the mantle and gills.

Table 1

Results of two-way ANOVA for effects of locality and gender on mercury concentrations in all tissues analysed

\begin{tabular}{lclllll}
\hline & Arm & Mantle & $\begin{array}{l}\text { Digestive } \\
\text { gland }\end{array}$ & $\begin{array}{l}\text { Branchial } \\
\text { heart }\end{array}$ & Gill & Gonad \\
\hline Locality & $\mathbf{3 1 . 7 6}$ & $\mathbf{9 . 9 1}$ & $\mathbf{9 . 9 1}$ & $\mathbf{9 . 9 1}$ & $\mathbf{7 . 5 4}$ & 0.31 \\
& $\mathbf{( 0 . 0 0 )}$ & $\mathbf{( 0 . 0 1 )}$ & $\mathbf{( 0 . 0 1 )}$ & $\mathbf{( 0 . 0 1 )}$ & $\mathbf{( 0 . 0 3 )}$ & $(0.59)$ \\
Gender & 3.51 & 3.31 & 3.31 & 3.31 & 1.99 & 0.04 \\
& $(0.08)$ & $(0.11)$ & $(0.11)$ & $(0.11)$ & $(0.20)$ & $(0.85)$ \\
\hline
\end{tabular}

The table shows the values of $F$, followed by the associated probability $(p)$ in parentheses. Significant correlations are shown in bold face. 
Table 2

Correlations between concentration of mercury in tissues, and weight, total length, GSI, DGI, and maturation state

\begin{tabular}{llccrrr}
\hline & Arm & Digestive gland & Mantle & Branchial heart & Gill & Gonad \\
\hline Weight & $-0.204(0.525)$ & $0.443(0.149)$ & $-0.195(0.543)$ & $0.113(0.728)$ & $-0.038(0.906)$ & $-0.060(0.853)$ \\
Total length & $-0.335(0.288)$ & $0.392(0.207)$ & $-0.332(0.292)$ & $0.046(0.887)$ & $-0.182(0.572)$ & $-0.241(0.451)$ \\
GSI & $-0.166(0.606)$ & $0.407(0.189)$ & $-0.103(0.750)$ & $0.293(0.356)$ & $-0.116(0.719)$ & $-0.414(0.181)$ \\
DGI & $0.185(0.564)$ & $-0.375(0.230)$ & $0.313(0.321)$ & $-0.041(0.900)$ & $0.157(0.627)$ & $0.382(0.221)$ \\
Maturity & $-0.07(0.83)$ & $0.35(0.27)$ & $-0.11(0.73)$ & $0.43(0.17)$ & $0.04(0.91)$ & $-0.43(0.16)$ \\
\hline
\end{tabular}

Correlations are Pearson's coefficients except for maturation state, for which Spearman's test was used. The table shows the values of $r$, followed by the associated probability $(p)$ in parentheses.

To provide an overview of similarities between levels of mercury in different tissues, we used cluster analysis (Fig. 4). From this analysis, it is apparent that patterns of mercury concentration in arm, mantle, and gill are very close. Values in the digestive gland were most dissimilar from the others.

The percentage of $\mathrm{Hg}$ contained in each tissue in relation to total mercury in the animal (the structures analysed represent $92 \%$ of total weight of animals) can be seen in Fig. 5. The arm is the tissue with the highest percentage of mercury, $56 \%$, followed by the digestive gland with $31 \%$.

\section{Discussion}

\subsection{Factors influencing $\mathrm{Hg}$ concentrations}

Metal concentrations in marine molluscs may vary with biological factors, such as age, size, and sex

Table 3

Results of Pearson's correlation between the levels of mercury in tissues analysed

\begin{tabular}{llllll}
\hline Tissues & Mantle & $\begin{array}{l}\text { Branchial } \\
\text { hearts }\end{array}$ & Gills & Gonads & $\begin{array}{l}\text { Digestive } \\
\text { gland }\end{array}$ \\
\hline Arm & $\mathbf{0 . 9 3}$ & $\mathbf{0 . 7 8}$ & $\mathbf{0 . 9 1}$ & 0.57 & 0.19 \\
& $\mathbf{( 0 . 0 0 )}$ & $\mathbf{( 0 . 0 0 )}$ & $\mathbf{( 0 . 0 0 )}$ & $(0.05)$ & $(0.56)$ \\
Mantle & & $\mathbf{0 . 7 9}$ & $\mathbf{0 . 9 3}$ & $\mathbf{0 . 5 8}$ & 0.10 \\
& & $\mathbf{( 0 . 0 0 )}$ & $\mathbf{( 0 . 0 0 )}$ & $\mathbf{( 0 . 0 4 9 )}$ & $(0.75)$ \\
Branchial & & & $\mathbf{0 . 7 7}$ & 0.29 & $\mathbf{0 . 5 8}$ \\
hearts & & & $\mathbf{( 0 . 0 0 )}$ & $(0.37)$ & $\mathbf{( 0 . 0 4 9 )}$ \\
Gills & & & & $\mathbf{0 . 6 4}$ & 0.09 \\
& & & & $\mathbf{( 0 . 0 3 )}$ & $(0.77)$ \\
Gonads & & & & & -0.27 \\
& & & & & $(0.40)$
\end{tabular}

The table shows the values of the $r$, followed by the associated probability $(p)$ in parentheses. Significant correlations are shown in bold face.
(Braune, 1987; Sadiq and Alan, 1992; EPA, 2001). However, no differences between genders were found for Portuguese octopus, which is consistent with results reported for those from the Azores Islands (Monteiro et al., 1992). Previous studies on octopods provide conflicting results on relationships between contaminant burden and body size. O. vulgaris from the Azores Islands exhibited significant relationships between mercury concentration, weight, and length (Monteiro et al., 1992). However, Barghigiani et al. (1991) found no relationship between mercury concentration and length of E. cirrhosa in the Tyrrhenian Sea despite finding such a relationship in fish and crustacean species. A second study of E. cirrhosa in the Tyrrhenian Sea (Rossi et al., 1993) showed that the concentration of mercury was correlated with length.

The quantity and concentration of mercury in tissues of octopus from Cascais was higher than in Viana. This may be related to differences in concentration of mercury in seawater. Data from INAG (National Institute of Water) indicate that the level of mercury in seawater at Viana do Castelo (Lima Coast) was around $0.012 \mu \mathrm{g} / \mathrm{l}$, and the level near Cascais, in the Tagus coast station, was around $0.025 \mu \mathrm{g} / \mathrm{l}$.

The discharges that contributed most to contamination of mercury in the Tagus estuary are from the following industries: chlorine production, ustulated pyrites, and the production of cement (Simas, 1998). Another consideration is that upwelling along the continental shelf at Cascais brings minerals to the surface, where mercury can settle to the bottom sediment, be absorbed by phytoplankton, or ingested by zooplankton, other microorganisms, or fish (IPCS, 2003).

Concentrations levels of mercury in seawater in Cascais were more or less double the levels in Viana. 


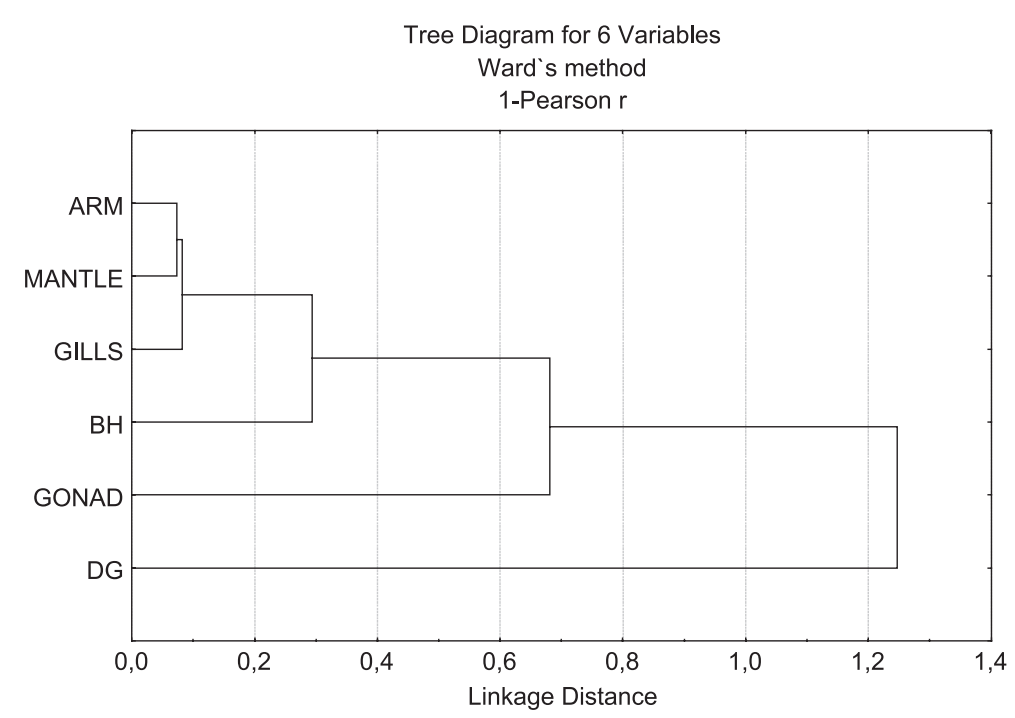

Fig. 4. Tree diagram of Ward's method (Pearson) for the tissues analysed.

Our results show that concentrations of mercury in the branchial hearts and in the arms of octopus in Cascais were almost double the concentrations found in Viana. In digestive glands, the mean concentration of mercury in Cascais was 5.9 times higher than the mean concentration of mercury in Viana do Castelo.

Among the different organs analysed, the digestive gland displayed the highest $\mathrm{Hg}$ concentrations, which strongly suggests that food is a major pathway for mercury accumulation in octopus. Correlation between the concentrations in the digestive gland and branchial hearts might be related to the excretory function of this tissue, as previously reported for other trace elements (Bustamante et al., 2002). Although there is no direct correlation with arms or mantle, the fact that muscular tissues contained most of the body's burden of mercury (arms and mantle) suggests that transfer of $\mathrm{Hg}$ from the digestive gland would occur.

The diet of octopus is based on molluscs, crustaceans, and fishes. Schuhmacher et al. (1994), in a study of concentration of mercury in marine species, concluded that the groups that accumulated more mercury are crustaceans and fishes.

In the muscle (a bivalve), accumulation from food is an important route, although accumulation from seawater is also pronounced, especially for inorganic

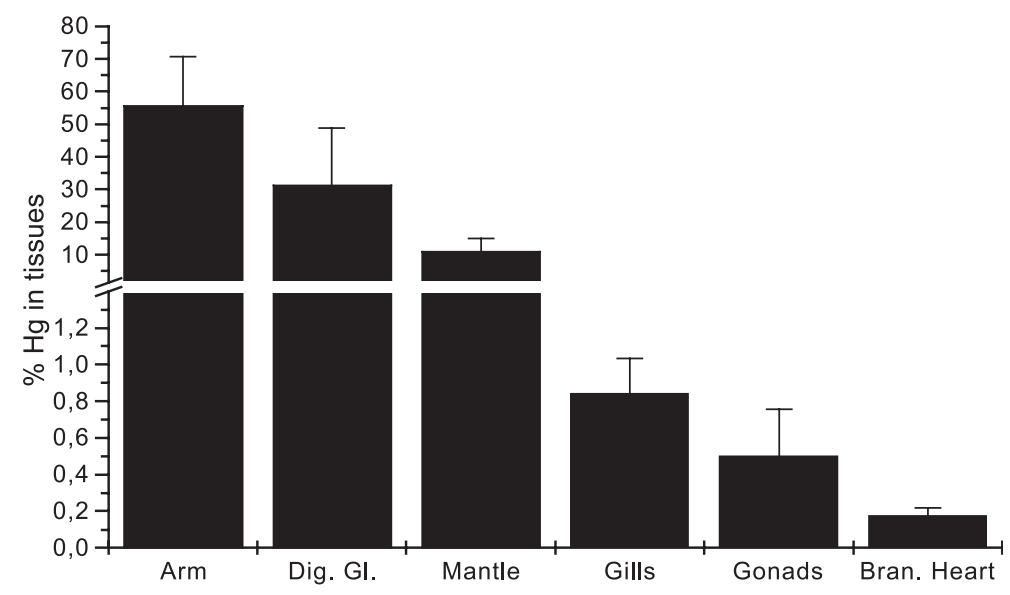

Fig. 5. Percentage distribution of mercury in tissues analysed. Values calculated on a wet weight basis. 
Table 4

Values for concentration of mercury from this study and from the literature on cephalopods

\begin{tabular}{|c|c|c|c|c|c|c|c|c|}
\hline Species & Locality & $\begin{array}{l}\text { Digestive } \\
\text { gland }\end{array}$ & $\begin{array}{l}\text { Branchial } \\
\text { hearts }\end{array}$ & Gills & Mantle & Arms & Gonads & Authors \\
\hline \multirow[t]{5}{*}{ Octopus vulgaris } & Viana & $0.58 \pm 0.08$ & $0.27 \pm 0.03$ & $0.28 \pm 0.05$ & $0.27 \pm 0.04$ & $0.22 \pm 0.08$ & $0.28 \pm 0.09$ & Present study \\
\hline & Cascais & $3.43 \pm 2.57$ & $0.52 \pm 0.07$ & $0.42 \pm 0.10$ & $0.48 \pm 0.16$ & $0.43 \pm 0.12$ & $0.36 \pm 0.22$ & Present study \\
\hline & Tyrrhenian Coast & $111.2 \pm 83^{\mathrm{a}}$ & & $1.17 \pm 0.55^{\mathrm{a}}$ & & $1.65 \pm 0.64^{\mathrm{a}}$ & $0.8 \pm 0.27^{\mathrm{a}}$ & Renzoni et al. (1973) \\
\hline & Kastela Bay (Adriatic) & & & & 0.52 & & & Buzina et al. (1989) \\
\hline & Modena (Italy) & & & & $0.04^{\mathrm{a}}$ & & & Plessi et al. (2001) \\
\hline Octopus salutii & South Adriatic Sea & $0.84 \pm 0.46^{\mathrm{a}}$ & & & $0.27 \pm 0.08^{\mathrm{a}}$ & & & Storelli and Marcotrigiano (1999) \\
\hline Eledone cirrhosa & Northern Tyrrhenian Sea & & & & $0.01-1.82^{\mathrm{a}}$ & & & Barghigiani et al. (2000) \\
\hline Eledone moschata & Modena (Italy) & & & & $0.023^{\mathrm{a}}$ & & & Plessi et al. (2001) \\
\hline \multirow[t]{2}{*}{ Ozoena moschata } & Kastela Bay (Adriatic) unpolluted & & & & 0.505 & & & Buzina et al. (1989) \\
\hline & Kastela Bay (Adriatic) polluted & & & & 0.370 & & & Buzina et al. (1989) \\
\hline Illex coindetti & South Adriatic Sea & $0.12 \pm 0.05^{\mathrm{a}}$ & & & $0.07 \pm 0.02^{\mathrm{a}}$ & & & Storelli and Marcotrigiano (1999) \\
\hline \multirow{3}{*}{ Todarodes pacificus } & Pacific coast & $0.053^{\mathrm{a}}$ & & & $0.085^{\mathrm{a}}$ & & & Ichihashi et al. (2001b) \\
\hline & Sea of Japan & $0.053^{\mathrm{a}}$ & & & $0.093^{\mathrm{a}}$ & & & Ichihashi et al. (2001b) \\
\hline & Nemuro Strait & $0.024^{\mathrm{a}}$ & & & $0.075^{\mathrm{a}}$ & & & Ichihashi et al. (2001b) \\
\hline Todarodes sagittatus & Azores & & & & $0.05 \pm 0.008$ & & & Monteiro et al. (1992) \\
\hline Loligo patagonica & Argentina & & & & 0.012 & & & Falandysz (1989) \\
\hline \multirow[t]{3}{*}{ Loligo vulgaris } & Kastela Bay (Adriatic) unpolluted & & & & 0.255 & & & Buzina et al. (1989) \\
\hline & Kastela Bay (Adriatic) polluted & & & & 0.322 & & & Buzina et al. (1989) \\
\hline & Modena (Italy) & & & & $0.089^{\mathrm{a}}$ & & & Plessi et al. (2001) \\
\hline Loligo forbesi & Azores & & & & $0.108 \pm 0.007^{\mathrm{a}}$ & & & \\
\hline Squid & Brixham & & & & 0.058 & & & MAFF (1998) \\
\hline Squid & Fraserburgh & & & & 0.016 & & & MAFF (1998) \\
\hline Squid & Newlyn & & & & 0.046 & & & MAFF (1998) \\
\hline Squid & United States & & & & 0.08 & & & Cappon and Smith (1982) \\
\hline Squid king & & & & & $0.02-0.22$ & & & Nagakura et al. (1974) \\
\hline Stenoteuthis oualaniensis & Iriomote Island (Japan) & 0.05 & & & & & & Ichihashi et al. (2001a) \\
\hline \multirow[t]{7}{*}{ Sepia officinallis } & Sado estuary (Portugal) & 0.20 & & & 0.10 & & & Alcobia (1995) \\
\hline & La Spezia (Mediterranean) & & & & 0.34 & & & Stoeppler et al. (1979) \\
\hline & Maddalena (Mediterranean) & & & & 0.20 & & & Stoeppler et al. (1979) \\
\hline & Chioggia & & & & 0.16 & & & Stoeppler et al. (1979) \\
\hline & Kastela Bay (Adriatic) unpolluted & & & & 0.236 & & & Buzina et al. (1989) \\
\hline & Kastela Bay (Adriatic) polluted & & & & 0.483 & & & Buzina et al. (1989) \\
\hline & Ceuta & & & & 0.13 & & & Stoeppler et al. (1979) \\
\hline
\end{tabular}

Values are in $\mathrm{mg} \mathrm{kg}^{-1}$ dry weight

${ }^{a} \mathrm{mg} \mathrm{kg}^{-1}$ wet weight.

b Muscle. 
mercury (Boening, 2000). Turoczy et al. (2001) indicated that mercury occurs preferentially in the muscle tissues in the king crab. Accumulation of mercury in the gonads is a concern, because the early stages of animals are apparently the most sensitive of the invertebrate life cycle (Boening, 2000).

Our results for concentrations of mercury in the digestive gland were consistent with results for Octopus salutii (Storelli and Marcotrigiano, 1999; see Table 4), although lower than the exceptionally high value of $111 \mathrm{mg} / \mathrm{kg}$ (wet weight) determined by Renzoni et al. (1973) for O. vulgaris on the Tyrrhenian coast. Levels of mercury in branchial hearts, gills, and gonads recorded in this study were slightly lower than those found by Renzoni et al. (1973), the latter values being two orders of magnitude lower than values for the digestive gland. We found few other data on mercury levels in these tissues in the literature. In the mantle and arm (muscle), values for this study were within the range found in the literature for cephalopods (see Table 4).

\subsection{Transfer to consumers}

The maximum permitted level of mercury allowed for human consumption is $0.5 \mathrm{mg} \mathrm{kg}^{-1}$ fresh weight (EC, rule $\mathrm{n}^{\circ} 466 / 2001$ ), which corresponds to approximately $2.5 \mathrm{mg} \mathrm{kg}^{-1}$ dry weight (in octopus arms). Portugal has signed the Paris convention, in which it was established that the maximum level of mercury in animals for human consumption is $0.3 \mathrm{mg}$ $\mathrm{kg}^{-1}$ wet weight (i.e., $1.5 \mathrm{mg} \mathrm{kg}^{-1}$ dry weight). The quantities that we measured in the arms and mantle of the octopus, the parts of the animal that are usually consumed by humans, are lower than these values. In certain areas, people eat the gills, but, again, levels of mercury are not high enough to cause concern. Probably the short life of octopus does not allow it to accumulate high quantities of mercury. Other authors who have examined the safety of octopus flesh for human consumption, in terms of mercury levels, have also concluded that total mercury concentrations did not exceed the maximum permitted (Rossi et al., 1993; Storelli and Marcotrigiano, 1999).

In conclusion, we can say that levels of mercury in octopus in Portugal are not sufficiently high to be harmful to humans, but a further, wider scale, study would be valuable.

\section{References}

Alcobia, H. Biologia e acumulação de mercúrio no choco Sepia officinallis (Linnaeus, 1758) do estuário do Sado. Relatório de estágio de licenciatura. IPIMAR and FCUL; Lisboa, 1995. 46 p.

Barghigiani G, Pellegrini D, Dulivo A, Deranieri S. Mercury assessment and its relation to selenium levels in edible species of the Northern Tyrrhenian Sea. Mar Pollut Bull 1991;22:406-9.

Barghigiani C, Ristori T, Biagi F, De Reneri S. Size-related mercury accumulations in edible marine species from an area of the Northern Tyrrhenian sea. Water, Air, Soil Pollut 2000; 124:169-76.

Bennett P, Jepson P, Law R, Jones B, Kuiken T, Baker J, et al. Exposure to heavy metals and infectious disease mortality in harbour porpoises from England and Wales. Environ Pollut 2001;112(1):33-40.

Bloom N. On the chemical form of mercury in edible fish and marine invertebrate tissue. Can J Fish Aquat Sci 1992;49:1010-7.

Boening D. Ecological effects, transport, and fate of mercury: a general review. Chemosphere 2000;40:1335-51.

Braune B. Mercury accumulation in relation to size and age of Atlantic herring (Clupea harengus) from the southwestern Bay of Fundy, Canada. Arch Environ Contam Toxicol 1987;16:311-20.

Bustamante P, Teyssié J, Fowler S, Cotret O, Danis B, Miramand P, et al. Biokinetics of zinc and cadmium accumulation and depuration at different stages in the life cycle of the cuttlefish Sepia officinalis. Mar Ecol, Prog Ser 2002;231:167-77.

Buzina R, Suboticanec K, Vukusic J, Sapunar J, Antonic K, Zorica M. Effect of industrial pollution on seafood content and dietary intake of total and methylmercury. Sci Total Environ 1989;78: $45-57$.

Cappon C, Smith J. Chemical form and distribution of mercury and selenium in edible seafood. J Anal Toxicol 1982;6(1): $10-21$.

Dietz R, Riget F, Born EW. An assessment of selenium to mercury in Greenland marine animals. Sci Total Environ 2000;245:15-24.

EPA. Water quality criterion for the protection of human health: methylmercury. Office Science and Technology, Office of Water. Washington; 2001. 253 pp.

Falandysz J. Trace metal in the raw and tinned squid Loligo patagonica. Food Addit Contam 1989;6(4):483-8.

Frisk, P. Expressions of Mercury-Selenium interections in vitro. Comprehensive Summaries of Uppsala Dissertations from the Faculty of Medecine; 2001. 62 pp.

Gilmour C, Henry E. Mercury methylation in aquatic systems affected by acid deposition. Environ Pollut 1991;71:131-69.

Gonçalves J. Octopus vulgaris Cuvier, 1797 (polvo comum): sinopse da biologia e exploração. Provas de Aptidão Pedagógica e Científica Universidade dos Açores; 1993. 447 pp.

Goyer R. Toxic effects of metals. Casarett and Doull's Toxicology The Basic Science of Poisons, 5 ed. New Cork: McGraw-Hill; 1995. p. $691-736$.

Guerra A. Determinación de las diferentes fases del desarrollo sexual de Octopus vulgaris Lamarck, mediante un índice de madurez. Investig Pesq 1975;39(2):397-416.

Horvat M. Mercury - do we know enough? In Trace element speciation for environmental, food and health. In: Ebdon L, Pitts 
S, Cornelis R, Crews H, Donard O, Quevauviller Ph. editors. London, UK: Royal Society of Chemistry; 2001. p. 127-41.

Ichihashi H, Kohno H, Kannan K, Tsumura A, Yamasaki S. Multielemental analysis of purple back flying squid using high resolution inductively coupled plasma-mass spectrometry (HR ICP-MS). Environ Sci Technol 2001a;35:3103-8.

Ichihashi H, Nakamura Y, Kannan K, Tsumura A, Yamasaki S. Multi-elemental concentration in tissues of Japanese common squid (Todarodes pacificus). Arch Environ Contam Toxicol 2001b;41:483-90.

IPCS. Elemental mercury and inorganic mercury compounds: human health aspects. Concise Int Chem Doc 2003;50:1-52.

Isani G, Andreani G, Kindt M, Carpene E. Metallothioneins (MTs) in marine molluscs. Cell Mol Biol 2000;46:311-30.

Landis $\mathrm{W}, \mathrm{Yu} \mathrm{M}-\mathrm{H}$. Introduction to environmental toxicology Impacts of chemicals upon ecological systems. 2nd ed. Washington: Lewis Publishers; 1999. 390 pp.

Law E. Aquatic Pollution. 2nd ed. New York: John Wiley and Sons; 1993. $415 \mathrm{pp}$.

MAFF. Concentrations of metals and other elements in marine fish and shellfish. Food Surveillance Information Sheet. MAFF 1998; $151: 1-13$.

Monteiro L, Porteiro F, Gonçalves J. Inter- and intra-specific variation of mercury levels in muscle of cephalopods from the Azores Arquipelago. Life Earth Sci 1992;10:13-22.

Nagakura K, Arima S, Kurihama M, Koga T, Fujita T. Mercury content of whales. Bull Tokai Reg Fish Res Lab 1974;78:41-6.

NAS. Seafood Safety. Washington: National Academy of Science; 1991. $452 \mathrm{pp}$.

NAS. Toxicological Effects of Methylmercury. Washington: National Academy Press; 2000368 pp.

Peterson, M., Chen, Y., Alarie, Y., Gunn, J., 2003. Research Project 6: Interactions of mercury and selenium in bioaccumulation processes. Université du Quebec à Montreal.www.unites. uqam.ca/comern/theme3/project36_03.html.

Pinho A, Guimarães J, Costa A, Olavo A, Valentin J. Total Mercury in muscle tissue of five shark species from Brazilia offshore waters: effects of feeding habit, sex, and length. Environ Res Sect, A 2002;89:250-8.

Plessi M, Bertelli D, Monzani A. Mercury and selenium content in selected seafood. J Food Compos Anal 2001;14:461-7.

Regnell O, Tunlid A. Laboratory study of chemical speciation of mercury in lake sediment and water under aerobic and anaerobic conditions. Appl Environ Microbiol 1991;57:789-95.
Renzoni A, Bacci E, Falciai L. Mercury concentration in water, sediments and fauna of an area of the Tyrrhenian Coast. Rev Int Oceanogr Med 1973;31-32:17-45.

Rossi A, Pellegrini D, Belcari P, Barghigiani C. Mercury in Eledone cirrhosa from the northern Tyrrhenian Sea: contents and relations with life cycle. Mar Pollut Bull 1993;26(12): $683-6$.

Sadiq M, Alan I. Bioccumulation of mercury by clams (Meretrix meretrix) collected from the Saudi Coast of the Arabian Gulf. Chem Speciat Bioavailab 1992;4(1):9-17.

Schuhmacher M, Batist J, Bosque M, Domingo J, Corbella J. Mercury concentrations in marine species from the coastal area of Tarragona Province, Spain Dietary intake of mercury through fish and seafood consumption. Sci Total Environ 1994;156(3): 269-73.

Silva L, Sobrino I, Ramos F. Reproductive biology of the common octopus, Octopus vulgaris Cuvier, 1797 (Cephalopoda: Octopodidae) in the Gulf of Cádiz (SW Spain). Bull Mar Sci 2002;71(2):837-50.

Simas M. Contaminação por mercúrio em alguns níveis tróficos da cala do norte-estuário do Tejo Tese para obetnção do grau de Mestrado. Lisboa: FCT-UNL; 1998. 121 pp.

Smith W, Smith A. Minamata. New York: Holt, Rinehart and Wiston; $1975192 \mathrm{pp}$.

Stoeppler W, Bernhard M, Backhaus F, Schulte E. Comparative studies on trace metal levels in marine biota: I. Mercury in marine organisms from western Italian coast, the strait of Gibraltar and the North Sea. Sci Total Environ 1979;13:209-23.

Storelli M, Marcotrigiano G. Cadmium and total mercury in some cephalopods from the south Adriatic Sea (Italy). Food Addit Contam 1999;16(6):261-5.

Turoczy N, Bradley D, Nicholas J, Levingsa A, Andrew H, Rajendram S. Cadmium, copper, mercury, and zinc concentrations in tissues of the King Crab (Pseudocarcinus gigas) from southeast Australian waters. Environ Int 2001;27:327-34.

WHO. Evaluation of mercury, lead, cadmium and food additives amaranth, diethylpyrocarbonate, and octyl gallate. WHO Tech Rep Ser 1972;505:1-19.

WHO. Methylmercury. Environ Health Criteria 1990;101:1-80.

WHO. International Programme on Chemical Safety, Environmental Health Criteria for Methylmercury. Geneva: World Health Organization; 2003. p. 1-120. 